\title{
The Effect of Metacognitive Strategy Instruction on Listening Performance, Metaconitive awareness and Listening anxiety of Beginner Iranian EFL Students
}

\author{
Roya Movahed ${ }^{1}$ \\ ${ }^{1}$ English Department, University of Zabol, Zabol, Iran \\ Correspondence: Roya Movahed, English Department, University of Zabol, Zabol, Iran. E-mail: \\ roya_movahed@yahoo.com
}

Received: December 23, 2013 Accepted: February 17, 2014 Online Published: March 28, 2014

doi:10.5539/ijel.v4n2p88

URL: http://dx.doi.org/10.5539/ijel.v4n2p88

\begin{abstract}
The present study investigated the effect of metacognitive strategy instruction on the listening performance, metacognitive awareness, and listening anxiety of EFL beginner students. The participants were 65, male and female, Iranian beginner EFL students, studying English translation and teaching in University of Zabol, Iran. After screening the participants through the TOEFL's listening section as the pre-test, 55 of them were selected and randomly divided into experimental $(n=30)$ and control $(n=25)$ groups. Besides the TOEFL's listening section, the Metacognitive Awareness Listening Questionnaire (MALQ) adapted from Vandergrift, Goh, Mareschal and Tafagdodtari (2006) and Foreign Language Listening Anxiety Scale (FLLAS) developed by Kim (2005) were also administered to the experimental group. After a period of 8-session strategy instruction to the experimental group based on Vandergrift and Tafaghodtari (2010) model of strategy instruction, the experimental and control group's listening performance were compared using the TOEFL's listening section as the post-test. Moreover the MALQ and FLLAS were also administered to the experimental group at the end of the treatment in order to investigate the effectiveness of the treatment. The results revealed that the experimental group significantly outperformed the control group on the post-tests and so the positive effect of the metacognitive strategy instruction on students' listening performance, metacognitive awareness and listening anxiety were verified.
\end{abstract}

Keywords: metacognition, metacognitive strategies, metacognitive strategy instruction, metacognitive awareness, listening comprehension, listening anxiety

\section{Introduction}

No one can ignore the remarkable role of listening in our perceptions of the world around us and in what we know as communication. Unless what is said is comprehended efficiently by the audience, we cannot claim that the communicative goal is reached. So teaching that kind of comprehension is of primary importance (Rivers, 1983). Numerous mental processes are involved in decoding the spoken language and giving meaning to what is heard known as listening comprehension strategies. Acknowledging and enabling students to use these strategies more efficiently would ease the comprehension process and would make listeners much more competent and elf confident. Goh (2008) mentions some positive effects of metacognitive strategy instruction on students' listening performance asserting that teaching students how to use them not only increases their sense of self confidence but also decreases their listening anxiety.

\section{Review of Related Literature}

\subsection{Metacognitive Strategies and Listening}

According to Flavell (1976) metacognition is a process in which the person is actively monitoring, controlling and arranging the cognitive process in order to attain cognitive goals. Flavell (1979) defines metacognition as to be aware of one's own cognitive processes and products or everything else which is relevant like those aspects of information related to the learning process. O'Malley and Chamot (1990, p. 44) believe that metacognitive strategies are "higher order executive skills that may entail of planning for, monitoring, or evaluating the success of activity". According to Harris (2003) views metacognition as a guiding process to learning in which the learner is using strategies to plan, monitor and evaluate language use and language learning. 
It has been proven that metacognitive strategies are really effective in enhancing learners' listening performance:

Rubin (1975) tried to investigate the effect of metacognitive strategy instruction on Spanish high school students' video comprehension and found that students' affect and motivation highly improved when videos were selected thoughtfully and effective learning strategies wee acquired. Thompson and Robin (1996), in a study on high school students learning Russian, found similar results of the effect of metacognitive strategy instruction on students' listening management.

Nakata (1999) found evidence of the effect of metacognitive strategy instruction on Japanese EFL students' perception, especially for those whose scores on G-TELP were rather low.

Carrier (2003) employing both bottom-up and top-down approaches to listening, instructed selective attention and note taking by first explaining and modeling the strategies and then getting students, to practice the strategies. The results testified the effectiveness of strategy training on their listening.

Vandergrift (2003) trained some university students in France how to make predictions about what they were going to listen, appraising their predictions and discussing and reflecting about what strategies they used in order to comprehend the text. The findings successfully proved the effectiveness of metacognitive strategy training on increasing students' motivation and understanding of their own learning.

The study carried out by Goh and Taib (2006) on some primary school pupils to teach metacognitive strategies and that of Graham and Macara (2008) on 68 lower-intermediate French students in England to measure the effectiveness of metacognitive strategies on learners' listening performance and their self-efficacy also verify the previous findings.

Vandergrift and Tafaghodtari (2010) assigned some metacognitive processes like prediction, planning, monitoring, evaluating and problem-solving to an experimental group of 59 French students in which the experimental group successfully outperformed the control group.

Still in recent years there have been some other studies demonstrating the positive effect of metacognitive strategy instruction on learners' listening comprehension like the study by Abdullah Coşkun (2010) on some beginner preparatory school learners at a university in Turkey or that of Birjandi and Rahimi (2012) on Iranian EFL university students.

\subsection{Models of Metacognitive Strategy Training}

Discovering the efficiency of metacognitive strategy training, some models have been proposed by some researchers including the steps and procedures the teachers must take to meet the training goals (Oxford et al., 1990; O’Malley \& Chamot, 1990).

O'Malley and Chamot (1990) proposed two approaches in strategy training: Direct training in which the instructor informs students of the importance and the goal of the strategies to be instructed and embedded training which is the acquisition of some strategies embedded in the texts and learning materials without directly being informed about them. Many researchers such as Wenden (1998) criticize embedded training for not being so effective for students dealing with new tasks.

"The strategy training model" proposed by O'Malley and Chamot (1990) consists of three phases of instruction: 1. The preparation phase in which the instructor awakens learners' earlier knowledge about the topic to be discussed. 2. The presentation phase during which the new information is presented to the students. 3 . The application and integration phase which serves to evaluate and internalize the learning task.

“Cognitive academic language learning approach" proposed by Chamot and O’Malley (1994) is another well-known instructional model which is based on Anderson's (2002) distinction between declarative knowledge, that kind of information dealing with facts, propositions or schemata stored in long term memory, and the procedural knowledge which is knowing how to accomplish different things like the most complicated cognitive skills and using learning strategies (O’Malley \& Chamot, 1990).

According to Birjandi and Rahimi (2012), The CALLA consists of three elements: topics from the main content subjects, increasing the academic language skills, and direct training of the learning strategies for both content and language. General principles applying CALLA model are: first diagnosing those strategies students already possess then selecting some new strategies to be taught, introducing and explaining the purpose and advantages of using them to the students. After that the teacher models using the strategies through performing some tasks and provides students with sufficient activities and tasks to practice using strategies. Asking students to write about or discuss about the strategies they have used completing the task would enable them to evaluate their own strategy use. The last step is empowering learners to actually use the strategies they have acquired in new 
contexts.

There is also another model of strategy instruction proposed by Vandergrift and Tafaghodtari (2010) which has been used as the model of strategy instruction in the present study. The stages of strategy instruction in this model are as follows:

- Prelistening: planning/predicting stage

1. After introducing the topic to the students, they can predict about the information or vocabularies they may encounter while listening to the text.

- First listen: first verification stage

2. Students evaluate their initial predictions to see if they were true, correct them if needed and pay attention to the new information understood.

3. Students compare what they have understood or written together to perceive and modify their weak points to rehearse more.

- Second listen: second verification stage

4. Students verify those points upon which they were not quite agree, try to correct them and add those new points and details they've understood.

5. All students take part in a discussion in which each one tries to share those main point they've understood about the text and how they reached those inferences.

- Third listen: final verification stage

6. Students listen more carefully with specific attention to those points mentioned in class discussion which they themselves could not understand in the previous listening.

- Reflection stage

7. Here students try to specify and write down some goals for the next listening based on the earlier discussion about the strategies they've used to comprehend the audio and those parts they have not understood.

\subsection{Listening Anxiety}

Foreign language anxiety has been defined as "a distinct complex of self-perceptions, beliefs, feelings, and behaviors related to classroom language learning arising from the uniqueness of the language learning process" (Horwitz, Horwitz, \& Cope, 1986, p. 128). It's believed to be a crucial factor causing failure in second language acquisition (Horwitz, 2001; Dornyei, 2005). Kondo and Ling (2004) also emphasize the potential problems that may arise for language learners due to learning anxiety. According to Horwitz (2001) there is a positive correlation between anxiety and students' poor performance in language learning. Those students feeling anxious learning a foreign language would not enjoy the experience which in turn would lead to poor performance (Gregersen \& Horwitz, 2002).

Most studies on foreign language anxiety carried out in the past were concentrated on oral anxiety; however, the focus has been shifted toward other skills such as listening which is an inevitable part of foreign language learning (Kimura, 2008).

Bekleyen (2009) defines foreign language listening anxiety (FLLA) as a kind of anxiety aroused in situations which need listening. Scarcella and Oxford (1992) have noted that learners experience listening anxiety in situations that they perceive as too much difficult or unfamiliar. Young (1992) states that listening comprehension would result in too much anxiety if students cannot comprehend the discourse. Some researchers believe that insufficient focus on listening, poor teaching methodologies, unsuitable and less-effective listening strategies besides learners' lack of vocabulary are important factors that may result in students' poor performance on L2 listening (Arnold, 2000; Vogely, 1998; Young, 1992).

Kim (2000) developed Foreign Language Listening Anxiety Scale (FLLAS), 33 five-point likert-type items, for measuring foreign language learners' listening anxiety which he administered to 253 Korean EFL students. The results of factor analysis indicated two factors: tension and worry, and also lack of self confidence in English listening regardless of students' gender or career. Kimura (2008) carried out the same study by administering FLLAS to Japanese EFL learners. Running factor analysis he discovered emotionality, worry, and anticipatory fear to be the three most important factors hindering listening process. There were no significant difference in the three factors considering gender. But considering "emotionality", the levels of majors were significantly different. 
In an study by Elkhafaifi (2005) FL learning anxiety and listening anxiety turned out to be quite separate but interrelated constructs correlated negatively. Monolingual learners were proved to experience higher anxiety levels than bilinguals (Legac, 2007). The results of a study among Turkish teacher candidates by Bekleyen (2009) revealed high levels of FLLA resulting in such effects as avoidance and physical symptoms.

\section{The Present Study}

Listening is more than just perceiving the sounds. It is a complex problem-solving skill in which the meaning of words, phrases, clauses, sentences and the discourse must be comprehended. It is a difficult skill to acquire even in one's own language, let alone in an unfamiliar foreign language (Oxford, 1993).

As an EFL teacher, I've always witnessed and perceived the difficulties students have understanding a foreign discourse as the flow of words and sentences sails to their ears. I've seen their terror and great anxiety decoding the mass of incoming data and I've felt strongly that using traditional method o teaching listening, i.e., asking students to listen to a text and retelling or discussing what they heard, is not quite responding. They need to be taught how to react to the unknown. They need to be equipped with some efficient techniques and strategies to overcome the obstacles and the great fear of listening to a foreign language and to be able to regulate and develop a systematic learning. So the present study was conducted to investigate the effectiveness of teaching metacognitive strategies on the listening performance, metacognitive awareness, and listening anxiety of a group of beginner Iranian EFL students with the hope of reaching some fruitful promising results to be applied practically in classroom contexts. To this aim the following research questions were formulated for this study:

- Does metacogntive strategy instruction affect students' listening performance?

- Does metacognitive strategy instruction have any effect on students' metacogntive awareness of listening?

- What is the effect of metacognitive strategy instruction on students' listening anxiety?

\section{Methodology}

\subsection{Participants}

The participants for the study were a group of 65 male and female Iranian beginner EFL students, between 18 to 21 years old, studying English translation and English teaching in University of Zabol. After screening the participants through the listening section of the TOEFL as the pre-test, 55 of them were randomly assigned to experimental $(\mathrm{n}=30)$ and control $(\mathrm{n}=25)$ groups.

\subsection{Instruments}

1. The listening section of the TOEFL as pre-test and post-test to measure both groups listening performance at the beginning and end of the study. It consisted three sections involving fifty questions. In the first section there were short conversations between two people after each there was a question about what had been stated or implied. In second and third sections some longer talks about general issues were played again with some questions after each talk to be answered by the participants.

2. A series of listening texts in various lengths and topics ranging from easier to much more challenging ones from the beginning up to the end of the instruction.

3. Metacognitive awareness listening questionnaire (MALQ), a 21 item questionnaire adapted from Vandergrift, Goh, Mareschal and Tafaghodtari (2006), as a pre-test and post-test to measure participants' metacognitive awareness of listening before and after the instruction (Appendix A). It is a 6-point likert scale ranging from strongly disagree (1) to strongly agree (6), measuring five factors: planning-evaluation, problem solving, mental translation, person knowledge, and directed attention among the students.

4. Foreign Language Listening Anxiety Scale (FLLAS) developed by Kim (2000), a 33 5-point likert scale ranging from strongly disagree (1) to strongly agree (5), administered to the participants, as a pre and post test to compare students' degree of listening anxiety before and after the instruction (Appendix B).

\subsection{Procedure}

One week before the treatment, both groups were administered the MALQ and FLLAS questionnaires along with some instructions and explanations answering them. After that the listening section of the TOEFL were administered as the pre-test based on which 55 students were selected and were randomly assigned to experimental $(n=30)$ and control $(n=25)$ groups. The experimental group received the instruction while the control group did not receive any treatment.

The experimental group participated in a 8-session strategy training, held twice a week and lasted for 45 minutes 
each time, based on the model presented by Vandergrift and Tafaghodtari (2010), the stages of which were explained before in the review of related literature, with the focus on planning, monitoring and evaluation strategies.

Every session a different listening text was played for the students their length and degree of difficulty increased little by little up to the end of the treatment as students were gaining mastery over strategy implementation. The steps involved in strategy instruction were as follows:

- First of all the teacher explained in general about different types of learning strategies (cognitive, metacognitive and socioaffective) along with some examples. Since the focus was on metacognitive strategies, some handouts representing Vandergrift (1997) taxonomy of cognitive and metacognitive listening strategies were distributed among the participants to provide them with some elaborate definitions about the metacognitive strategies of planning, monitoring and evaluation strategies (Appendix C). Some examples were also provided to make students familiar with their actual use in listening contexts.

- In the planning/predicting stage, after introducing the topic of the listening text to the students, they were asked to write it on a piece of paper along with some brainstorming about the related information and vocabularies they predicted they might hear. Then they were asked to attend to the main listening task and not being distracted by irrelevant distracters.

- In the first verification stage, students listened to the listening text for the first time and were asked to check their predictions on the list they had written before to see which one of them were true, correct them if needed and write down the new information comprehended. After that in pairs or groups they compared their understandings, discussed the points of disagreement and made decisions on the parts of the text that needed more attention during the second phase of listening.

- In the second verification stage, for the second time they listened to the listening text making corrections and added new points they perceived during the listening. After that in a class discussion students discussed about what they comprehended by telling the important points of the text and explained on the way they drew those inferences about what they heard.

- In the final verification stage, if there were any point revealed in the discussion that students had not understood before, they tried to listen much more carefully to get those special points in the final listening.

- In the last stage which is the reflection stage, students reflected upon the listening process and decided upon the goals and strategies to be used in the next listening task.

After the treatment was over, students on both groups were administered another listening comprehension test as the post-test in order to compare the control and experimental groups' performance to percieve if the strategy instruction had had any effect in the experimental groups' listening performance. The MALQ and FLLAS were also administered to the experimental group at the end of the treatment in order to compare their pre and post-test results and investigate the metacognitive strategy instruction effect on students' metacognitive awareness and listening anxiety.

\section{Results and Discussions}

\subsection{Results and Discussions Considering the First Research Question}

In order to answer the first research question regarding the effect of metacognitive strategy training on students' listening performance, the mean scores of both groups on the TOEFL post-test were to be compared together. To do so, first the equality of both groups before treatment had to be proven by comparing the mean scores of both groups in the pre-test. In order to compare two independent means, equality of variances had to be calculated using Leven's test. The p-value was calculated to be 0.450 , that is bigger than 0.05 , so the variances were assumed to be equal with $95 \%$ confidence. Comparing the equality of means for two independent groups is reached through an independent samples t-test. So a two-tailed t-test was used to compare the means. Since the p-value was 0.348 which is bigger than 0.05 it was verified that the mean scores between two groups were not significantly different and so the control and experimental groups were initially equal considering their listening performance. Table 1 illustrates the statistical analysis for investigating equality of means. 
Table 1. Descriptive statistics for investigating two groups' mean scores on the pre-test

\begin{tabular}{ccccccc}
\hline Pre-test & N & Mean & SD & df & t-value & sig \\
\hline Experimental group & 30 & 21.64 & 4.72 & 53 & 1.73 & 0.348 \\
Control group & 25 & 19.38 & 5.21 & & & \\
\hline
\end{tabular}

After the homogeneity of the two groups before treatment was confirmed, it was needed to check whether there was any change in students' listening performance after the treatment. So a paired t-test was employed to compare the mean scores of the experimental group before and after the treatment. As indicated in table 2, the p-value was estimated to be 0.000 , which is smaller than 0.05 and so it was concluded that there was a significant difference between the mean scores of the experimental group before and after the treatment. Based on these results it was evident that the listening performance of the students in the experimental group was significantly improved through strategy instruction.

Table 2. Descriptive statistics showing progress in the experimental group

\begin{tabular}{ccccccc}
\hline Experimental group & $\mathbf{N}$ & Mean & SD & df & t-value & sig \\
\hline Pre-test & 30 & 21.64 & 4.72 & \multirow{2}{*}{29} & \multirow{2}{*}{3.10} & \multirow{2}{*}{0.000} \\
Post-test & 30 & 25.58 & 5.62 & & & \\
\hline
\end{tabular}

And finally the mean scores in the control and experimental group' post-test were compared using an independent t-test. As illustrated in table 3, the p-value was 0.000 that is less than 0.05 , and so it was quite clear that the experimental group had significantly outperformed the control group and so the positive effect of strategy instruction on students' listening performance was verified.

Table 3. Descriptive statistics comparing control and experimental groups' post-tests

\begin{tabular}{ccccccc}
\hline Post-test & N & Mean & SD & df & t-value & sig \\
\hline Experimental group & 30 & 25.58 & 5.62 & \multirow{2}{*}{53} & \multirow{2}{*}{3.73} & 0.000 \\
Control group & 25 & 19.98 & 5.79 & & & \\
\hline
\end{tabular}

\subsection{Results and Discussions Considering the Second Research Question}

Investigating the second research question, the data obtained from the pre and post administration of MALQ were compared using t-test. The items related to each 5 factors in the MALQ (planning and evaluation, problem solving, mental translation, person knowledge and directed attention) were as follows:

Table 4. Factors of MALQ and their related items

\begin{tabular}{ccc}
\hline Factors & Items no. & Total (21) \\
\hline Planning and evaluation & $1,8,12,20,21$ & 5 \\
Problem solving & $3,6,9,13,17,19$ & 6 \\
Mental translation & $4,11,16$ & 3 \\
Person knowledge & $5,10,15$ & 3 \\
Directed attention & $2,7,14,18$ & 4 \\
\hline
\end{tabular}

The questionnaire is a 6-point likert scale ranged from strongly disagree (1), disagree (2), partially disagree (3), partially agree (4), agree (5), to strongly agree (6) and so the scores for each item vary between 1 to 6 . After transferring scores to the appropriate row, the mean was calculated for each factor to measure students' awareness on each factor before and after the treatment. Then the general mean of the pre-test and post-test was calculated and compared. Since the level of significance turned out to be less than 0.05 , it was concluded that 
there is a significance difference between students' metacognitive awareness before and after the strategy instruction and so the positive effect of the treatment on students' metacognitive awareness was verified. The results have been presented in the following table.

Table 5. Statistical summary of pre and post-test of total MALQ

\begin{tabular}{llllll}
\hline MALQ & N & Mean & SD & t-value & sig \\
\hline Pre-test & 30 & 45.26 & 3.22 & 0.721 & 0.00 \\
Post-test & 30 & 53.36 & 4.23 & & \\
\hline
\end{tabular}

\subsection{Results and Discussions Considering the Third Research Question}

Analyzing the third research question, the mean scores of the students in the pre and post administration of FLLAS were compared using t-test. Since it is a 5-point likert scale, the scores for each item vary between (1) strongly disagree to (5) strongly agree and so students' scores on the questionnaire may vary between 49 (the least level of anxiety) to 149 (the highest level of anxiety). Comparing the mean scores in the pre and post-test reveals that students' FLLA has decreased at the end of the treatment. The p-value also turned out to be less than 0.05 which confirms the difference between students' degree of FLLA before and after the treatment. So it can be concluded that metacognitive strategy instruction can decrease students' degree of FLLA. The statistical results are as follows:

Table 6. Statistical summary of pre and post-test of total FLLA

\begin{tabular}{cccccc}
\hline FLLA & N & Mean & SD & t-value & sig \\
\hline Pre-test & 30 & $96 / 1$ & 27.48 & 5.11 & 0.00 \\
Post-test & 30 & $67 / 36$ & 16.66 & & \\
\hline
\end{tabular}

\section{Conclusion and Pedagogical Implications}

The results of the study indicates that metacognitive strategy instruction has a positive effect on students' listening performance which is consistent with the findings represented by Vandergrift and Tafaghodtari (2010), Graham and Macaro (2008), Goh and Taib (2006), and Vandergrift (2002, 2003a).

When students learn how to plan, monitor, and evaluate themselves in a listening task, they can manage their own learning and so become self-regulated and much more competent in their performance. As Vandergrift (2002, p. 573) states "teaching for metacognition provides language learners with the knowledge and tools for meaningful transfer of learning so that they know how to listen to and understand authentic texts outside of the classroom".

The findings also demonstrates that metacognitive strategy training can be strongly effective in increasing students' metacognitive awareness to deal with listening tasks much more tactfully, to plan in advance for the strategies to be used and to be aware and responsible for their own learning.

The students' degree of FLLA also decreased through the period of strategy instruction. Language anxiety has been referred by many scholars as having a negative debilitative effect on learning process. Kondo and Ling (2004), for example, believe that anxiety may result in learners' reduced speech and may hinder their understanding of spoken language. So finding a way to deal with such a destructive factor in the process of learning is quite vital. When students feel more comfortable and relaxed, they can learn much better.

The results of this study provide some pedagogical implications for teachers to be applied in classroom contexts. Making use of metacognitive strategies can improve students' listening performance, metacognitive awareness and listening anxiety. It makes students self regulated and responsible for their own learning. So it's a time for teachers, especially those in Iran, to replace the traditional product-oriented methods of teaching listening with the process-oriented ones with a greater focus on strategic listening which is much more promising in students' progress.

\section{References}

Anderson, N. J. (2002). The role of metacognition in second language teaching and learning. Washington, DC: 
Center for Applied Linguistics. ERIC. Clearinghouse on Language and Linguistics.

Arnold, J. (2000). Seeing through listening comprehension exam anxiety. TESOL Quarterly, 34, 777-786. http://dx.doi.org/10.2307/3587791

Bekleyen, N. (2009). Helping teachers become better English students: Causes, effects, and coping strategies for foreign language listening anxiety. System, 37, 664-675. http://dx.doi.org/10.1016/j.system.2009.09.010

Birjandi, P., \& Rahimi, A. H. (2012). The effect of metacognitive strategy instruction on the listening performance of EFL students. International Journal of Linguistics, 4, 495-517. http://dx.doi.org/10.52996/ijl.v4i2.1707

Carrier, K. A. (2003). Improving high school English language learners' second language listening through strategy instruction. Bilingual Research Journal, 27, 383-410. http://dx.doi.org/10.1080/15235882.2003.10162600

Chamot, A. U., \& O’Malley, J. M. (1994). The CALLA handout: Implementing the cognitive academic language learning approach. White Plains, NY: Addison Wesley Longman.

Coşkun, A. (2010). The effect of metacognitive strategy training on the listening performance of beginner students. Research on Youth and Language, 4, 35-50.

Dörnyei, Z. (2005). The psychology of the language learner: Individual differences in second language acquisition. Mahwah, NJ: Lawrene Erlbaum. http://dx.doi.org/10.1177/0261927X05281424

Elkhafaifi, H. (2005). Listening comprehension and anxiety in the Arabic language classroom. The Modern Language Journal, 89(2), 206-220. http://dx.doi.org/10.1111/j.1540-4781.2005.00275.x

Flavell, J. H. (1976). Metacognitive aspects of problem solving. In L. B. Resnick (Ed.), The nature of intelligence. Hillsdale, NJ: Erlbaum.

Flavell, J. H. (1979). Metacognition and cognitive monitoring: A new area of cognitive-developmental inquiry. American Psychologist, 34, 906-911. http://dx.doi.org/10.1037/0003-066X.34

Goh, C. (2008). Metacognitive instruction for second language listening development: Theory, practice and research implications. Regional Language Centre Journal, 39(2), 188-213.

Goh, C., \& Taib, Y. (2006). Metacognitive instruction in listening for young learners. ELT Journal, 60, 222-232. http://dx.doi.org/10.1093/rlt/cc1002

Graham, S., \& Macaro, E. (2008). Strategy instruction in listening for lower-intermediate learners of French. Language Learning, 58, 747-783. http://dx.doi.org/10.1111/j.1467-9922.2008.00478.x

Gregersen, T., \& Horwitz, E. (2002). Language learning and perfectionism: Anxious and non-anxious language learner's reactions to their own oral performance. The Modern Language Journal, 86(iv), 562-570. http://dx.doi.org/10.1111/1540-4781.00161

Harris, V. (2003). Adapting classroom-based strategy instruction to a distance learning context. TESOL Internet Journal, 7(20).

Horwitz, E. K. (2001). Language anxiety and achievement. Annual Review of Applied Linguistics, 21, 112-126. http://dx.doi.org/10.1017/S0267190501000071

Horwitz, E. K., Horwitz, M. B., \& Cope, J. (1986). Foreign language classroom anxiety. The Modern Language Journal, 70, 125-132. http://dx.doi.org/10.1111/j.1540-4781.1986.tb05256.x

Kim, J. H. (2000). Foreign language listening anxiety: A study of Korean students learning English (Unpublished doctoral dissertation). University of Texas, Austin.

Kimura, H. (2008). Foreign language listening anxiety: Its dimensionality and group differences. JALT Journal, 30, 173-196.

Kondo, D. S., \& Ying-Ling, Y. (2004). Strategies for coping with language anxiety: The case of students of English in Japan. ELT Journal, 58, 258-265. http://dx.doi.org/10.1093/elt/58.3.258

Legac, V. (2007). Foreign-language anxiety and listening skill in Croation monolingual and bilingual students of EFL. In J. Horvath, \& M. Nikolov (Eds.), UPRT 2007: Empirical studies in English applied linguistics (pp. 217-243).

Nakata, Y. (1999). The effects of listening strategy training on listening competence. Paper, AILA, Tokyo.

O’Malley, J. M., \& Chamot, A. U. (1990). Learning strategies in second language acquisition. Cambridge, UK: 
Cambridge University Press. http://dx.doi.org/10.1017/CBO9781139524490

Oxford, R. L. (1990). Language learning strategies: What every teacher should know. Boston: Heinle \& Heinle.

Oxford, L. R. (1993). Research update on teaching L2 listening. System, 21(2), 205-211. http://dx.doi.org/10.1016/0346-251X(93)90042-F

Rivers, W. M. (1983). Communicating naturally in a second language: Theory and practice in language teaching. New York: Cambridge University Press.

Rubin, J. (1975). What the good language learner can teach us. TESOL Quarterly, 9, 41-45. http://dx.doi.org/10.2307/3586011

Scarcella, R., \& Oxford, R. (1992). The tapestry of language learning: The individual in the communicative classroom. Heinle \& Heinle, Boston, MA.

Thompson, I., \& Rubin, J. (1996). Can strategy instruction improve listening comprehension? Foreign Language Annuals, 29(3), 331-342. http://dx.doi.org/10.1111/j.1944-9720.1996.tb01246.x

Vandergrift, L. (1997). The comprehension strategies of second language (French) students: A descriptive study. Foreign Language Annuals. http://dx.doi.org/10.1111/j.1944-9720.1997.tb02362.x

Vandergrift, L. (2002). It was nice to see that our predictions were right: Developing metacognition in L2 listening comprehension. The Canadian Modern Language Review, 58, 555-575. http://dx.doi.org/10.3138/cmlr.58.4.555

Vandergrift, L. (2003). From prediction through reflection: Guiding students through the process of L2 listening. Canadian Modern Language Review, 59, 425-440. http://dx.doi.org/10.3138/cmlr.59.3.425

Vandergrift, L., \& Tafaghodtari, M. (2010). Teaching L2 learners how to listen does make a difference: An empirical study. Language Learning, 60, 467-470. http://dx.doi.org/10.1111/j.1467-9922.2009.00559.x

Vandergrift, L., Goh, C. C. M., Mareschal, C., \& Tafaghodtari, M. H. (2006). The Metacognitive Awareness Listening Questionnaire (MALQ): Development and Validation. Language Learning, 56(3), 431-462. http://dx.doi.org/10.1111/j.1467-9922.2006.00373.x

Vogely, A. J. (1998). Listening comprehension anxiety: Students' reported sources and solutions. Foreign Language Annuals, 31, 67-80. http://dx.doi.org/10.1111/j.1944-9720.1998.tb01333.x

Wenden, A. L. (1998). Metacognitive knowledge and language learning. Applied Linguistics, 19, 515-537. http://dx.doi.org/10.1093/applin/19.4.515

Young, D. J. (1992). Language anxiety from the foreign language specialist's perspective: Interactive with Krashen, Omaggio Hadley, Terrell, and Rubin. Foreign Language Annuals, 25, 157-172. http://dx.doi.org/10.1111/j.1944-9720.tb00524.x

Appendix A

\begin{tabular}{|c|c|c|c|c|c|c|}
\hline Factor & Belief/Perception & 1 & 2 & 3 & 4 & 5 \\
\hline 1. Planning/Evaluation & $\begin{array}{l}\text { Before I start to listen, I have a plan in my head for } \\
\text { how I am going to listen. }\end{array}$ & & & & & \\
\hline 2. Directed attention & $\begin{array}{l}\text { I focus harder on the text when I have trouble } \\
\text { understanding. }\end{array}$ & & & & & \\
\hline 3. Problem-solving & $\begin{array}{l}\text { I use the words I understand to guess the meaning } \\
\text { of the words I don't understand. }\end{array}$ & & & & & \\
\hline 4. Mental translation & I translate in my head as I listen. & & & & & \\
\hline 5. Person knowledge & $\begin{array}{l}\text { I find that listening in English is more difficult } \\
\text { than reading, speaking, or writing in English. }\end{array}$ & & & & & \\
\hline 6. Problem-solving & $\begin{array}{l}\text { As I listen, I compare what I understand with what } \\
\text { I know about the topic. }\end{array}$ & & & & & \\
\hline 7. Directed attention & $\begin{array}{l}\text { When my mind wanders, I recover my } \\
\text { concentration right away. }\end{array}$ & & & & & \\
\hline
\end{tabular}




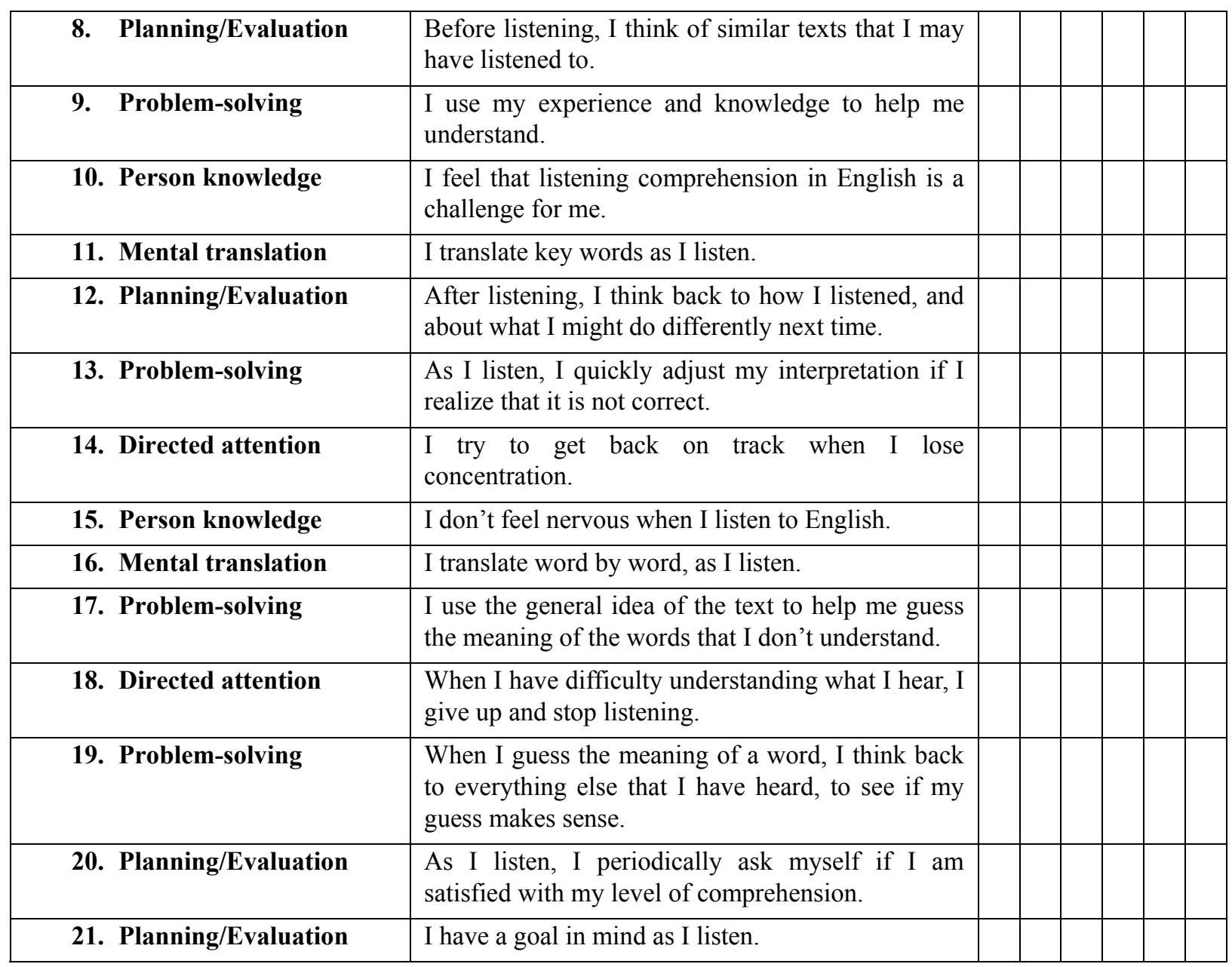

\section{Appendix B}

A Questionnaire on Foreign Language Listening Anxiety (FLLAS) developed by Kim (2000)
Name:
Level:
Gender:

Below is a list of statements dealing with your Foreign Language Listening Anxiety. For each statement, please indicate whether you strongly disagree (1), disagree (2), No idea (3), agree (4) or strongly agree (5). Please read each statement carefully, give your first reaction to each statement, and mark an answer for every statement.

\begin{tabular}{|c|c|c|c|c|c|c|}
\hline 1 & I get stuck with one or two unfamiliar words. & 1 & 2 & 3 & 4 & 5 \\
\hline 2 & I get nervous if listening test passages are read just once. & & & & & \\
\hline 3 & $\begin{array}{l}\text { It is difficult to understand people with English pronunciation that is different from } \\
\text { mine. }\end{array}$ & & & & & \\
\hline 4 & I worry that I might not be able to understand when people talk too fast. & & & & & \\
\hline 5 & I am nervous when I am not familiar with the topic. & & & & & \\
\hline 6 & It is easy to make guesses about the parts I missed. & & & & & \\
\hline 7 & I worry that I might have missed important information while I was distracted. & & & & & \\
\hline 8 & I am worried when I cannot see the lips or facial expressions of the person. & & & & & \\
\hline 9 & $\begin{array}{l}\text { I get nervous and confused when I don't understand every word in listening test } \\
\text { situations. }\end{array}$ & & & & & \\
\hline
\end{tabular}




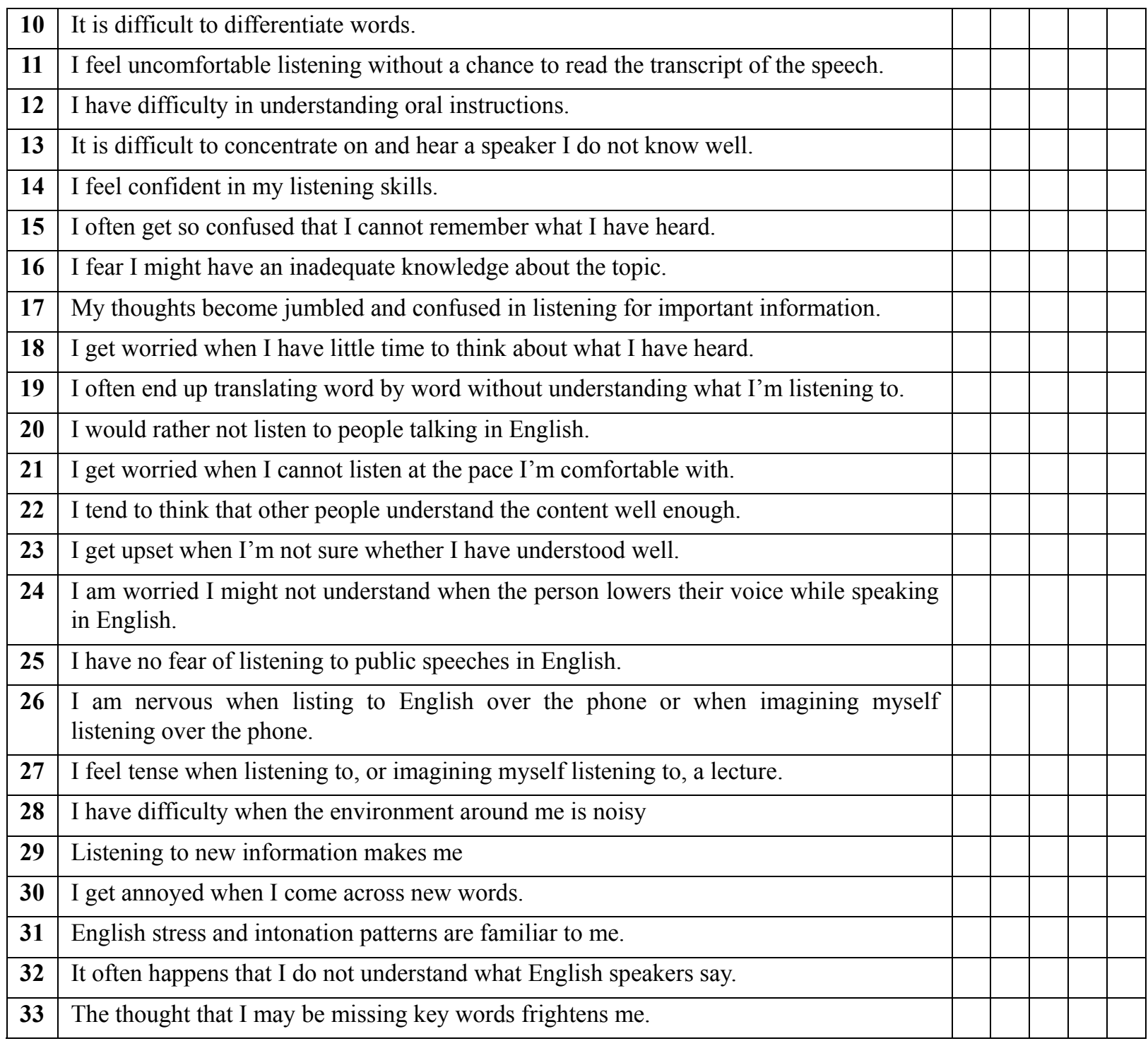

\section{Appendix C}

Vandergrift's (1997) Taxonomy of Metacognitive and Cognitive Listening Comprehension Strategies:

\section{Metacognitive strategies}

\section{Planning:}

Developing an awareness of what needs to be done to accomplish a listening task, developing an appropriate action plan and/or appropriate contingency plans to overcome difficulties that may interfere with successful completion of the task.

\section{1a. Advance organization:}

Clarifying the objectives of an anticipated listening task and/or proposing strategies for handling it.

\section{1b. Directed attention:}

Deciding in advance to attend in general to the listening task and to ignore irrelevant distracters; maintaining attention while listening.

1c. Selective attention: 
Deciding to attend to specific aspects of language input or situational details that assist in understanding and/or task completion.

1d. Self-management:

Understanding the conditions that help one successfully accomplish listening tasks and arranging for the presence of those conditions.

\section{Monitoring:}

Checking, verifying, or correcting one's comprehension or performance in the course of a listening task.

2a. Comprehension monitoring:

Checking, verifying, or correcting one's understanding at the local level.

\section{2b. Double-check monitoring:}

Checking, verifying, or correcting one's understanding across the task o during the second time through the oral text.

\section{Evaluation:}

Checking the outcomes of one's listening comprehension against an internal measure of completeness and accuracy.

\section{Problem identification:}

Explicitly identifying the central point needing resolution in a task or identifying an aspect of the task that hinders its successful completion.

\section{Copyrights}

Copyright for this article is retained by the author(s), with first publication rights granted to the journal.

This is an open-access article distributed under the terms and conditions of the Creative Commons Attribution license (http://creativecommons.org/licenses/by/3.0/). 